\title{
Skeletal Muscles with Antagonistic Muscular Actions: Morphological, Contractile and Metabolic Characteristics
}

\author{
Músculo Esquelético con Acción Muscular Antogonista: \\ Características Metabólicas, Contratiles y Morfológicas
}

"Carlos Eduardo A. de Freitas; *"Selma de Bastos Zambelli Freitas; ${ }^{* * * *}$ Francis da Silva Lopes; ${ }^{* * * *}$ Maeli Dal Pai-Silva $\&{ }^{* * * * * *}$ Ivan da Cruz Piçarro

DE FREITAS, C. E. A.; FREITAS, S. B. Z.; LOPES, F. S.; PAI-SILVA, M. D. \& PIÇARRO, I. C. Skeletal muscles with antagonistic muscular actions: morphological, contractile and metabolic characteristics. Int. J. Morphol., 27(4):1173-1178, 2009.

SUMMARY: The muscles can perform the same function in a specific segment (muscles of fast and slow contraction), and at the same time be antagonistic in relation to muscular action (flexors or extensors). The present research aimed to study the morphology, frequency and metabolism of fiber types and the contractile characteristics of extensor and flexors muscles of rabbit. We studied muscles anterior tibialis (AT), flexor digitorum supeficialis (FDS), extensor digitorum longus (EDL) and posterior tibialis (PT). The muscles were submitted to the techniques HE, NADH-TR and myofibrillar ATPase. In EDL and PT extensor muscles, the frequencies of red (SO + FOG) and white fibers (FG) were $68.77 \%$ and $31.23 \%$ versus $58.87 \%$ and $41.13 \%$, respectively. In the AT and FDS flexor muscles, these frequencies were $75.14 \%$ and $24.86 \%$ versus $73.89 \%$ and $26.11 \%$, respectively. In extensor muscles, the percentage of slow contraction fibers was $8.05 \%$ in EDL and 9.74\% in PT, and in fast contraction, 91.95\% in EDL and 90.26\% in PT. In flexors, the slow contraction frequencies were $12.35 \%$ in AT and $8.17 \%$ in FDS, and in fast contraction, $87.65 \%$ and $91.83 \%$, respectively. Skeletal muscles with antagonistic muscular actions (flexors and extensors) the morphological, contractile and metabolic characteristics are identical.

KEY WORDS: Contractile ability; Metabolic; Morphologic; Skeletal muscle.

\section{INTRODUCTION}

Striated skeletal muscle is constituted by different types of muscle fibers, with distinct metabolic and contractile characteristics. Currently muscle fibers are classified into fibers of slow contraction - Type I (Slow Fibers IA), expressing MHCI; and fibers of rapid contraction - Type II (Fast Fibers II A and II B), subdivided into type IIA, expressing MHC IIa; Type IID, expressing MHC IId and Type IIB, expressing MHC IIB. The fibers of type IID present histochemical and biochemical characteristics similar to those of IIX fibers described in rats (Larsson et al., 1991), mice and rabbits (Hämäläinem \& Pette, 1993).

The dynamic nature of muscle fiber types in mammals demonstrates that each fiber type presents different activities of metabolic enzymes. Histochemical analysis of muscle for activities of mitochondrial enzymes and mATPase permits the identification of fibers as being of slow contraction and oxidative metabolism; of fast contraction and glycolytic metabolism and of fast contraction and oxidative and glycolytic metabolism (Peter et al., 1972).

In mammals, muscles used in walking are constituted by a heterogeneous population of muscle fibers, with predominance of a determinate type of fiber conforming to its function. Muscle function, therefore, is one of the factors that can influence the distribution of different fiber types (Goldspink, 1999). The muscles can perform the same function in a specific segment (muscles of fast and slow contraction), and at the same time be antagonistic in relation to muscular action (flexors or extensors), as is the case for muscles involved in walking (Ariano et al., 1973; Hebel \& Stromberg, 1976).

\footnotetext{
* Department of Physiotherapy - UNOESTE, Presidente Prudente, Brasil.

** Department of Pharmacy and Biochemistry - UNOESTE, Presidente Prudente, Brasil.

**** Departments of Physiotherapy, UNOESTE, Presidente Prudente and Cell Biology and Anatomy, UNICAMP, Campinas, Brasil.

***** Department of Morphology, UNESP, Botucatu, Brasil.

${ }^{* * * * * *}$ Department of Physiology - UNIFESP, São Paulo, Brasil.
} 
Skeletal muscle possesses high plasticity that enables it to alter its morphological, metabolic and functional characteristics (Flück \& Hoppeler, 2003). Among the conditions that can alter muscular characteristics, denervation models have been proposed to evaluate muscular plasticity (Biral et al., 2008). The animal model most utilized in these studies has been the rabbit (Pai-Silva et al., 2001; Ashley et al., 2007). Studies demonstrate that in denervation the response of striated skeletal muscles in the rabbit is similar to that in humans, contrary to what occurs in rats under the same conditions (Ashley et al.). Given that the rabbit is being widely utilized as an experimental animal model, the knowledge on the morphological and biochemical characteristics of its different muscles is of fundamental importance. Thus, the study in the rabbit of distribution of its different fiber types (frequency) and metabolism is shown to be indispensable to knowledge on its morphofunctional and metabolic characteristics under physiological conditions. The present research will constitute a parameter for subsequent comprehension involving studies under other conditions with this experimental model.

Given these facts, the present research aimed to obtain data on contractile and metabolic characteristics, frequency and distribution of three basic fiber types in muscles with antagonistic action (extensors and flexors) related to walking.

\section{MATERIAL AND METHOD}

The present research utilized four adult male rabbits (Orictolagus cuniculus), of the New Zealand breed. The animals were anesthetized intramuscularly with acepromazine $2 \%$ and sacrificed with sodium thionenbutal by intravenous route. Next, after measurement of body weight and the left hindlimb, the AT, FDS, EDL and PT muscles were dissected and removed. The extensor and flexor muscles of the left hindlimb were utilized to study the morphological, metabolic and contractile characteristics frequency and distribution of the fiber types.For this, muscle segments were collected from the ventral region of each muscle, measuring approximately $1 \mathrm{~cm}$ in length $\mathrm{x} 0.5 \mathrm{~cm}$ in diameter. After remaining 5 to 10 minutes at room temperature, this material was submitted to cryobiological treatment, by immersion in $\mathrm{n}$-hexane, at $-70^{\circ} \mathrm{C}$, previously cooled at this temperature with the aid of liquid nitrogen (McMannus \& Mowry, 1964). Following two minutes at this temperature, the material was transferred to a "Cryocut 1850Reichert-Young", cryostat microtome chamber at $-20^{\circ} \mathrm{C}$, where it remained for 30 minutes. Thus were obtained various series of histological cuts, with $8 \mathrm{~mm}$ thickness, that were submitted to the following techniques: Hematoxylin and
Eosin, aiming to study the general morphology do tissue, Nicotinamide Adenine Dinucleotide Tetrazolium Reductase (NADH-TR) for demonstration of oxidative and glycolytic metabolic activities of muscle fiber (Dubowitz \& Brooke, 1972). Finally, in other series of histological cuts a reaction was developed to demonstrate slow and rapid contractile ability of fibers, by demonstration of myofibrillar ATPase enzyme (m- ATPase), at $\mathrm{pH} 9.4$, preceded by incubation in alkaline medium ( $\mathrm{pH} 10.4)$ and in acidic medium ( $\mathrm{pH} 4.4)$ (Peter et al., 1972). Reaction positivity after preincubation in alkaline medium indicates fast contractile ability (phasic) and reaction positivity in acidic $\mathrm{pH}$, slow contraction (tonic).

Analysis and description of morphology and characteristics of each histochemical reaction of muscle fibers were accomplished. These were classified and denominated SO, FOG and FG, according to criteria adopted by Peter et al., taking into account their diameters in transversal cuts, the intensity and cytological distribution of the reaction product for glycolytic and oxidative metabolism, NADH-TR reaction, and reactivity to reaction for myofibrillar ATPase, after preincubation in alkaline medium and in acidic media, to evaluate the contractile ability of muscle fiber types. Utilizing a microscope amplification equivalent to ocular 10X and objective 40X, frequencies (\%) of fiber types were sampled in 12 microscopic fields. For the metabolic activity the fibers were classified into reds and whites, in relation to contractile ability in slows and fasts. For this study an entirely randomized delineation was utilized and when there was significance for the F statistic, the Tukey test was also employed (Berquó et al., 1981).

\section{RESULTS}

The observation of cuts dyed by Hematoxylin - Eosin (HE) reveals that muscles are constituted by muscle fibers of different diameters, polygonal contours and various nuclei positioned peripherally to the cytoplasm (Fig. 1 a).

Transversal histological cuts of muscles, when submitted to NADH-TR reaction, which evidences oxidative and/or glycolytic metabolic activity, reveal three fiber populations with different reaction intensity. The fibers with shorter diameter reveal intense reactivity, especially in the subsarcolemmal region, being classified as type I; the fibers of greater diameter present weak reactivity, being type II B, those of moderate intensity and intermediate diameter or at times similar to type FG, correspond to type II A fibers ("mosaic pattern") (Fig. 1 b).

The flexor, AT and FDS muscles presented $75.14 \%$ 

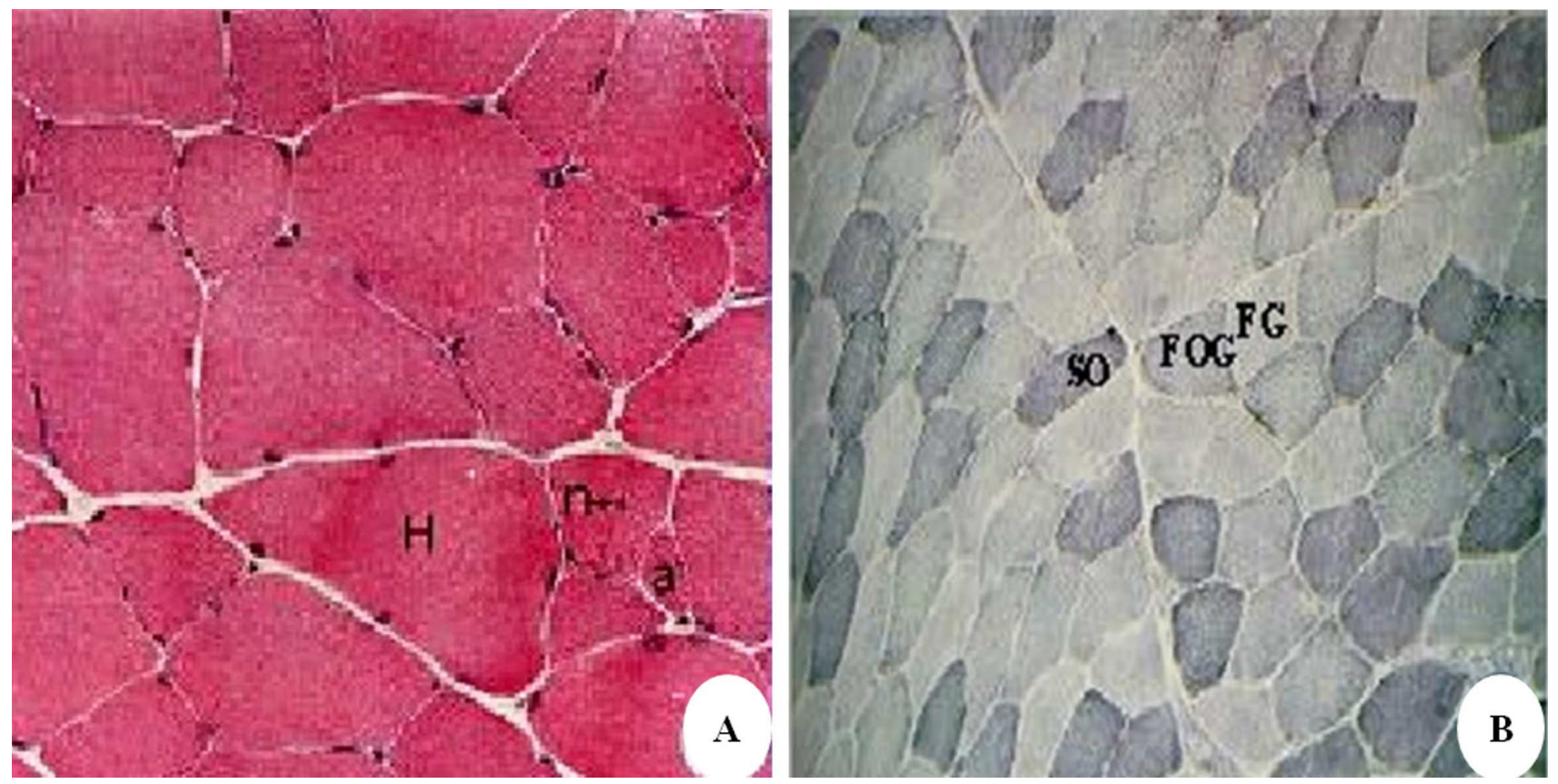

Fig 1. Transversal section of the flexor digitorum superficialia (FDS) of rabbit. A) muscle fibers (F) with polygonal shape and different diameters, peripherical nucleus (n) and endomysium (e) (HE 42.5x). B) SO, FOG and FG fibers identified by NADH-TR reaction (42.5x).

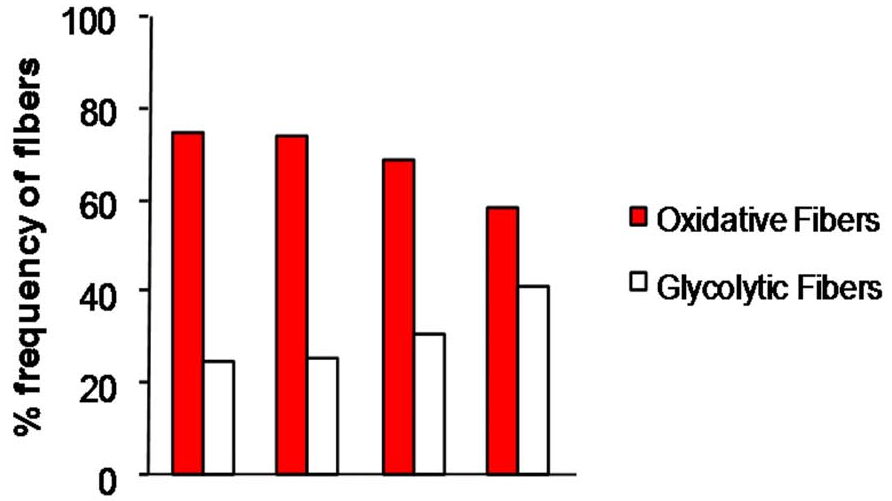

Fig. 2. Frequency of oxidatives (I + IIA) and glycolytic (IIB) fibers of anterior tibialis (AT), flexor digitorum superficialis (FDS), extensor digitorm longus (EDL) and posterior tibialis (PT) muscles.

and $73.89 \%$ of oxidative fibers (I + II A), respectively; $24.86 \%$ and $26.11 \%$ of glycolytic fibers (II B). Yet in the extensor, PT and EDL muscles, the frequencies of oxidative fibers were $58.87 \%$ and $68.77 \%$, respectively, and for glycolytic fibers, $41.13 \%$ and $31.23 \%$. In relation to metabolic activity in both muscle groups there was a predominance of oxidative fibers (I and II A), but in flexor muscles the values found were discretely higher (Fig. 2).

When the m-ATPase reaction, that permits classification of muscle fibers as fast or slow, is accomplished after preincubation at $\mathrm{pH} 10.4$, the type I fibers show low intensity of or even a negative reaction. Reactivity was demonstrated to be moderate in type II A and very intense in type II B. The observation of subsequent histological cuts submitted to this reaction after preincubation in acidic medium $(\mathrm{pH} 4.4)$, revealed an inverse pattern of reactivity, being very intense in type I fibers, weak to negative in type II B and moderate in type II A (Fig 3 a, b).

In flexor muscles, AT and FDS the frequency of slow contraction fibers with myosin (type I) was $12.35 \%$ and $8.17 \%$, respectively. The frequencies of fast contraction fibers of type II A were $58.44 \%$ and $61.53 \%$, and fast fibers of type II B were $29.21 \%$ and $30.30 \%$. The frequency of fibers with myosin of fast contraction (II A + II B) was $87.65 \%$ for the AT muscle and $91.83 \%$ for FDS muscles. In extensor, PT and EDL muscles, the frequencies of slow contraction fibers with myosin (type I) were $9.74 \%$ and $8.05 \%$, respectively. In these muscles frequencies of type II A fast contraction fibers were $56.70 \%$ and $61.53 \%$, respectively, and of type II B fibers, $33.56 \%$ and $29.65 \%$, respectively. The frequency of fibers with myosin of fast contraction was $90.26 \%$ in PT muscle and $91.85 \%$ in EDL muscle. The muscles studied presented greater frequency of fast contraction fibers with myosin, with type II A fibers predominant. In extensor muscles the values were slightly higher (Fig. 4). 

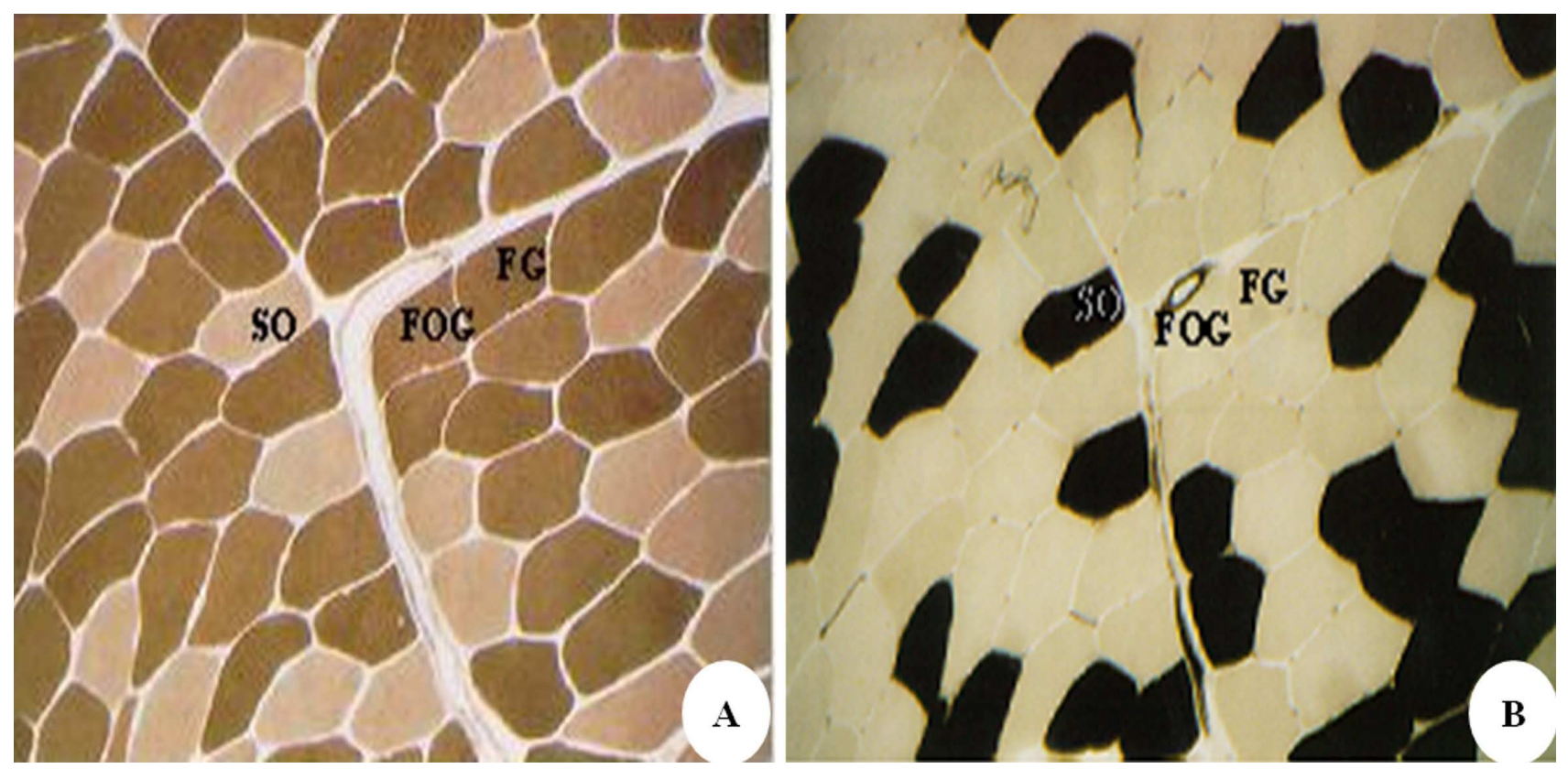

Fig 3. Serial transversal section of the extensor digitorum longus (EDL) of rabbit. A) slow contraction fibers (SO) and fast contraction fibers (FOG and FG) identified by m-ATPase reaction at $\mathrm{pH} 10.4$ (170x). B) slow contraction fibers (SO) and fast contraction fibers (FOG and FG) identified by m-ATPase reaction at pH 4.4 (170x).

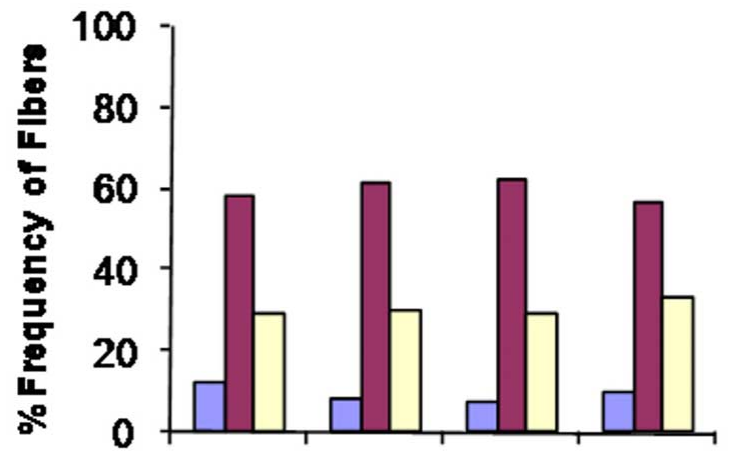

\section{口TypeIFibers}

$\square$ TypeIfFibers

$\square$ TypeIB Fibers
Fig. 4. Frequency of type I, type IIA and IIB fibers of anterior tibialis (AT), flexor digitorum superficialis (FDS), extensor digitorm longus (EDL) and posterior tibialis $(\mathrm{PT})$ muscles.

\section{DISCUSSION}

The present study demonstrated that in skeletal muscles with antagonistic muscular actions (flexors and extensors) the morphological, contractile and metabolic characteristics are identical. The animal model chosen, the rabbit, was adequate for the study since, according to McKoy et al., (1998), this specie presents a homogeneous population of muscle fibers among the various muscles. Ashley et al., demonstrated in an experimental model of denervation, that the rabbit can be a better choice than the rat, since the muscle alterations in denervation are similar to those in the human.
The four muscles selected for the present study possess antagonistic muscular actions. The EDL act in the extension of the metatarsals and PT, and in extension of the tarsus. Yet the FDS act in the flexing of the $2^{\text {nd }}, 3^{\text {rd. }}$ and $4^{\text {th }}$ metatarsals and the AT, in the flexing of the tarsus (Ariano et al.; Hebel \& Stromberg).

In the present study, variation was observed in the frequency of fiber types between the extensor and flexor muscles studied in the rabbit. The extensor muscles 
displayed $91.1 \%$ fast (type II) and $8.9 \%$ slow contraction fibers (type I). In flexor muscles these values were $89.2 \% \%$ of fast contraction fibers and $10.8 \%$ slow contraction ones. According to an article published by Prado et al. (2005) consisting of a review of contractile characteristics of anterior tibial and extensor digitorum longus muscles of rabbit by the techniques of electrophoresis and myofibrillar ATPase, fast contraction fibers predominated in both muscles.

Ashey et al. utilizing the rabbit experimental model, observed by myofibrillar ATPase that the AT muscle of this animal is composed of 3 fiber types (I, IIA and IIX), with a predominance of fast contraction fibers (type II). Gueguen et al., (2005), also utilizing the rabbit model, analyzed the AT muscle, but with a distinct technique (electrophoresis SDS - PAGE), and observed a predominance of myosin of a fast contractile pattern (IIA and IIX). Through biochemical analysis (electrophoresis) it was observed that fast myosins (IIA) predominate in rabbit EDL (Galler et al., 2005). In present study type IIB fibers were observed, since the technique utilized does not permit identification of IIX fibers.

Muscle function is one of the factors that can influence the distribution of different types of fibers (Goldspink, 1999). In mammals, the muscles for walking are constituted by a heterogeneous population of muscle fibers, with predominance of a determinate fiber type conforming with its function. The AT and EDL muscles present antagonistic muscular action, flexing of the tarsus and extension of toes, respectively. However, both have a function in walking. The modality of walking in the rabbit, which is accomplished, in great part, by execution of sudden impulses of the posterior limbs, may favor the activation of fast contraction fibers recruited in high velocity anaerobic activities that depend almost entirely on anaerobic metabolism (Gollnick et al., 1983). The slow contraction fibers are selectively recruited in aerobic activities (Karlsson \& Jacobs, 2003). Although one muscle group would be a flexor and the other an extensor with regard to their articular action, both muscle groups are related in walking in the studied specie, whose locomotor pattern is executed by impulses on its posterior limbs, which justifies the similarity between the contractile and metabolic patterns that predominate in high-velocity activities.

As in the majority of mammals, the muscles studied herein are constituted by a heterogeneous population of muscle fibers. It was possible to identify fibers of types I, IIA and IIB, with a predominance of type IIA fibers (fast contraction and both glycolytic and oxidative metabolism). The technique utilized (m-ATPase) does not permit the identification of other fiber types (IID/X).

The pattern of walking in the rabbit differs from that in most mammals, given that its locomotion is accomplished by means of hind-limb impulses. This factor can be determinative in the muscle fiber type predominant in the muscles studied, fast contraction fibers, since these muscles are related to dynamic non-static activity such as the postural muscles.

The muscles studied possess antagonistic muscular action (flexion and extension), but both are related to walking. It is concluded that the determinate factor for the prevalence of a specific type of muscle fiber muscular, and consequently of contractile ability, is not the action of a muscle with regard to articular movement (flexor or extensor), but rather its function is related to maintenance of posture or rapid and vigorous contractions.

DE FREITAS, C. E. A.; FREITAS, S. B. Z.; LOPES, F. S.; PAI-SILVA, M. D. \& PIÇARRO, I. C. Músculo esquelético con acción muscular antogonista: características metabólicas, contratiles y morfológicas. Int. J. Morphol., 27(4):1173-1178, 2009.

RESUMEN: Los músculos estriados esqueléticos pueden desempeñar la misma función en un segmento corporal específico (músculos decontracción rápida y lenta), y al mismo tiempo pueden ser antagonistas en relación a su acción muscular (flexores o extensores). El objetivo de esta investigación fue analizar la morfología, el metabolismo y la frecuencia de los tipos de fibras y las características contráctiles de músculos flexores y extensores del conejo. Fueron evaluados los músculos tibial anterior (TA), flexor superficial de los dedos (FDS), extensor largo de los dedos (EDL) y tibial posterior (TP). Los músculos fueron sometidos a las técnicas de Hematoxilina Eosina (HE), NADH-TR y ATPase miofibrilar. En los músculos extensores EDL y TP, las frecuencias de los tipos de fibras rojas (SO + FOG) y fibras blancas (FG) fueron de $68,77 \%$ y $31,23 \%$ versus $58,87 \%$ y $41,13 \%$, respectivamente. En los músculos flexores TA y FDS estas frecuencias fueron $75,14 \%$ y $24,86 \%$ versus $73,89 \%$ y $26,11 \%$, respectivamente. En los músculos extensores el porcentaje de fibras de contracción lenta fue 8,05\% en el EDL y 9,74\% en el TP; y las fibras de contracción rápida fue de 91,95\% en el EDL y 90,26\% en el TP. En los flexores la frecuencia de fibras de contracción lenta fue $12,35 \%$ en el TA y 8,17\% FSD, y las fibras de contracción rápida fue $87,65 \%$ y $91,83 \%$ respectivamente. Músculos esqueléticos con acción muscular antagónica (flexores y extensores) poseen características morfológicas, contráctiles y metabólicas idénticas.

PALABRAS CLAVE: Características contráctiles; Metabólicas; Morfológicas; Músculos esqueléticos. 


\section{REFERENCES}

Ariano, M. A.; Armstrong, R. B. \& Edgerton, V. R. Hind limb muscle fiber populations of five mammals. $J$. Histochem. Cytochem., 21:51-66, 1973.

Ashley, A.; Sutherland, H.; Lanmüller, H.; Russold, M. F.; Unger, E.; Bijak, M.; Mayr, W.; Boncompagni, S.; Protasi, F.; Salmons, S. \& Jarvis, J. C. Atrophy, but not necrosis, in rabbit skeletal muscle denervated for periods up to one year. Am. J. Physiol. Cell. Physiol., 292:440$51,2007$.

Berquó, E. S.; Souza, J. M. P.; Gotlied, S. L. D. \& Souza, J. F. P. Bioestatística. São Paulo, Pedagógica e Universitária (EDUSP), 1981. p.350.

Biral, D.; Kern, H.; Adami, N.; Boncompagni, S.; Protasi, F. \& Carraro, U. Atrophy-resistant fibers in permanent peripheral denervation of human skeletal muscle. Neurol. Res., 30(2):137-44, 2008.

Dubowitz, V. \& Brooke, M. H. Muscle Biopsy: A modern approach. Philadelphia, Saunders, 1972. p.432.

Flück, M. \& Hoppeler, H. Molecular basis of skeletal muscle plasticity from gene to form and function. Rev. Physiol. Biochem. Pharmacol., 146:156-216, 2003.

Galler, S.; Wang, B. G. \& Kawai, M. Elementary steps of the cross-bridge cycle in fast-twitch fiber types from rabbit skeletal muscles. Biophysical J., 89:3248-60, 2005.

Goldspink, G. Changes in muscle and phenotype and the expression of autocrine and systemic growth factors by muscle in response to stretch and overload. J. Anat., 19:323-34, 1999.

Gollnick, P. D. Músculo-esquelético: Estrutura e função. In: McArdley, W. D.; Katch, F. I. \& Katch, V. L. Fisiologia do Exercício. Energia, nutrição e desempenho humano. 5a ed. Rio de Janeiro, Guanabara Koogan, 2003. p.1113.

Gueguen, N.; Lefaucheur, L.; Fillaut, M. \& Herpin, P. Muscle fiber contractile type influences the regulation of mitochondrial function. Mol. Cell. Biochem., 276(12):15-20, 2005.

Hämäläinen, N. \& Pette, D. The histochemical profiles of fast fiber types IIB, IID, and IIA in skeletal muscles of mouse, rat, and rabbit. J. Histochem. Cytochem., 41:73343, 1993.
Hebel, R. \& Stromberg, M. W. Anatomy of the laboratory rat. Baltimore, William \& Wilkins Company, 1976. p.173.

Karlsson, J. \& Jabobs, I. Músculo-esquelético: Estrutura e função. In: McArdley, W. D.; Katch, F. I. \& Katch, V. L. Fisiologia do Exercício. Energia, nutrição e desempenho humano. 5a ed. Rio de Janeiro, Guanabara Koogan, 2003. p.1113.

Larsson, L.; Edström, L.; Lindegren, B.; Gorza, L. \& Schiaffino, S. MHC composition and enzymehistochemical and physiological properties of a novel fast-twitch motor unit type. Am. J. Physiol., 261:93-101, 1991.

McMannus, J. F. A. \& Mowry, R. W. Histochemical studies on developing mast cells. Anat. Rec., 150:265-9, 1964.

McKoy, G.; Léger, M. E.; Bacou, F. \& Goldspink, G. Diferential expression of myosin heavy chain mRNA and protein isoforms in four functionally, diverse rabbit skeletal muscles during pre-and postnatal development. Dev. Dyn., 211:81-100, 1998.

Pai-Silva, M. D.; Ueda, A. K.; Resende, L. A.; Pai, V. D.; Alves, A. \& Faleiros, A. T. Morphological aspects of rabbit masseter muscle after cervical sympathectomy. Int. J. Exp. Pathol., 82(2):123-8, 2001.

Peter, J. B.; Barnard, R. J.; Edgerton, V. R.; GillIespie, C. A. \& Stempel, K. E. Methabolic profiles of three fiber types of skeletal muscle in guinea pigs and rabbits. Biochemistry, 11:2627-37, 1972.

Prado, L. G.; Makarendo, I.; Andresen, C.; Krüger, M.; Optiz, C. A. \& Linke, W. A. Isoform diversity of giant proteins in relation to passive and active contractile properties of rabbit skeletal muscles. J. Gen. Physiol., 126(5):461-80, 2005.

\section{Correspondence to:}

Dr. Carlos Eduardo Assumpção de Freitas

Department of Physiotherapy - UNOESTE

Rua José Bongiovani, 700

CEP 19050-680, Presidente Prudente

São Paulo, BRASIL

Tel: +55 (018) 3229-1055.

Fax: +55 (018) 3229-1013

Email: cfreitas@unoeste.br

Received: 31-08-2009

Accepted: 05-11-2009 